\title{
ЗАСТОСУВАННЯ ПСИХОГРАФІЧНОЇ СЕГМЕНТАЦІї ДЛЯ НАЛАГОДЖЕННЯ КОМУНІКАЦІї У СФЕРІ ПІДГОТОВКИ ЛІКАРІВ
}

Національна медична академія післядипломної освіти імені П. Л. Шупика, м. Київ, Україна

\begin{abstract}
Мета: надати рекомендації для здійснення прицільної комунікації з ключовими групами споживачів послуг безперервного професійного розвитку на основі попередньої сегментації.

Матеріали і методи. Анкети 1768 респондентів, які представляють всі регіони України, щодо важливості чинників вибору фрорми безперервного профресійного розвитку піддано фракторному аналізу, за результатами якого отримано чотири фрактори, значення яких використано для проведення кластерного аналізу (метод к-середніх). Оцінку результатів здійснювали на основі даних дескриптивної статистики, статистичну вірогідність різниці показників визначали методами попарного порівняння та дисперсійного аналізу.

Результати. У результаті сегментування, здійсненого на основі аналізу анкет лікарів - споживачів освітніх послуг, виявлено чотири ключові фрактори вибору форми безперервного професійного розвитку: професійність, доступність навчального курсу, рівень соціальної активності, фрормалізм слухача, на основі яких утворено сім кластерів слухачів, що відрізняються за соціодемографічними та психографічними характеристиками.

Висновки. Критичними завданнями є оптимізація освітнього процесу, мінімізація документообігу, часу відриву від роботи фахівців, налагодження роботи з онлайн-медіа, облік, аналіз та комунікація з наявними освітніми послугами.
\end{abstract}

КЛЮЧОВІ СЛОВА: безперервний професійний розвиток; кадрові ресурси; соціальний маркетинг; кластерний аналіз; психографічна сегментація.

3 метою виживання закладів освіти під час різкого переходу з майже повного бюджетного фонансування на умови повної самоокупності, а також, враховуючи посилення конкурентного середовища (поява нових, у тому числі зарубіжних провайдерів освітніх послуг), необхідно оптимізувати стратегію просування закладу та механізми іiї реалізації з врахуванням наукових підходів [1, $3,4,9]$.

У перехідний період варто заволодіти увагою потенційних споживачів, які готові самостійно оплатити освітні послуги. За нашими дослідженнями для цього в комунікаційні повідомлення необхідно включати інформацію та додаткові пояснення щодо отримання результату навчання. Для задоволення потреб потенційних споживачів $€$ доцільним переорієнтувати навчальний процес на надання короткотривалих циклів (в середньому 5 робочих днів), значною мірою збільшити питому вагу циклів з елементами дистанційної освіти та виїзних циклів $[2,8]$.

Комунікаційні канали варто посилити представленням додаткової інфоомації щодо переваг та можливостей споживачів від проходження кожного конкретного навчального заходу.

Водночас необхідно проводити маркетингові заходи щодо підготовки групи потенційних споживачів із категорії «не готові платити» в категорію більш лояльних. Для цього слід поширювати по- відомлення 3 цікавою для цієї групи інфрормацією та очікувати, що вони зможуть відчути прихильність до отримання освітніх послуг пізніше.

Проте система мотиваторів до отримання послуг безперервного професійного розвитку (БПР) потребує детальнішого вивчення на базі визнаного наукового маркетингового підходу, яким $€$ сегментація [5, 10].

Мета дослідження: надати рекомендації для здійснення прицільної комунікації з ключовими групами споживачів послуг БПР на основі попередньої сегментації.

Матеріали і методи. Розроблено анкети для анонімного добровільного заповнення у паперовому або електронному вигляді. Отримано анкети 1768 респондентів, які представляють всі регіони України.

Згідно з рекомендаціями до проведення таких досліджень $[6,7,10]$, на першому етапі з метою виявлення основних фракторів впливу проведено факторний аналіз 15 чинників вибору форми БПР. За результатами виявлено чотири основні фрактори. Результат тесту Kaiser-Meyer-Olkin становив 0,78, що свідчить про досить високу адекватність запропонованого факторного рішення.

Сегментацію респондентів здійснювали за допомогою методу кластерного аналізу на основі отриманих факторів вибору форми БПР. Перевірка набору з семи кластерів, отриманих методом

(с Ю. В. Вороненко, О. П. Гульчій, Н. М. Захарова, К. В. Балашов, 2020 
к-середніх, за допомогою ієрархічних методів кластеризації довела стабільність запропонованого кластерного рішення (частка збігу основних груп становить $78 \%$ ).

Оцінку результатів здійснювали на основі даних дескриптивної статистики, статистичну вірогідність різниці показників у кластерах визначали методами попарного порівняння з поправкою Бонфрероні для відносних величин та за допомогою однофакторного дисперсійного аналізу (ANOVA) для середніх величин. Статистичну обробку та підготовку візуальних матеріалів проводили за допомогою пакета SPSS v. 23.

Результати дослідження та їх обговорення. Проведення фракторного аналізу чинників вибору форми БПР дозволило виявити чотири основні фактори: ефективність курсу БПР, його доступність, соціальну орієнтованість респондента, а також стійку схильність орієнтуватися на визнані зовнішні атрибути чи соціальні норми, що отримала назву «формалізм». Нижче наведені дані про фрактори, які роблять найбільший внесок у фрормування відповідного чинника (фактор 1 робить практично рівнозначні внески в 3-й та 4-й фрактори, тому їх подають в обох переліках):

1. Фактор 1. Ефрективність: ч. 5. Наявність відкритої інформації (наприклад, на сайті Академії) про мету та наповнення курсу, лекторів тощо; ч. 10. Участь міжнародних лекторів; ч. 11. Можливість підтримки діалогу 3 кафредрою після завершення циклу; ч. 12. Наявність матеріалів для дистанційного навчання; ч. 13. Можливість роботи з пацієнтами.

2. Фактор 2. Доступність: ч. 3. Територіальна зручність; ч. 6. Завантаженість; ч. 7. Необхідність поїздки в інше місто; ч. 8. Умови проживання в гуртожитку; ч. 9. Вартість циклу.

3. Фактор 3. Соціальність: ч. 2. Рекомендації друзів\колег; ч. 4. Відгуки осіб, які пройшли цей цикл раніше (розміщені у відкритих джерелах, співбесідах); ч. 1. Наявність попереднього досвіду навчання на цій кафедрі.

4. Фактор 4. Формалізм: ч. 1. Наявність попереднього досвіду навчання на цій кафедрі; ч. 14. Наявність серед лекторів професорів, докторів медичних наук; ч. 15. Наявність серед лекторів публічних осіб.

Для кожного респондента розраховано значення фракторів, що переважно перебувають в інтервалі від -3,0 до +3,0 (рис. 1). Медіанні значення фракторів для кожного отриманого кластера наведено у таблиці 1. Базуючись на значенні фракторів та вивченні поведінкових особливостей, запропоновано короткі назви для кожного кластера, покликані спростити сприйняття особливостей кожної групи та відмінностей між ними.

Аналіз найважливіших для респондентів 3 кожного кластера чинників свідчить, що:
- всі кластери, крім 1-го і 3-го, мають фрактори ефрективності серед найважливіших, а в 5-го та 6-го кластерів усі три найважливіших чинники є саме фракторами ефективності;

- всі кластери, крім 5-го та 6-го, включають у перелік найважливіших ч. 9 (вартість циклу);

- представники 1-го та 7-го кластерів мають у трійці найважливіших по 2 фактори доступності;

- лише у 1-му кластері в перелік найважливіших входить фрактор соціальності;

- лише у 3-му - чинник фрормалізму та ч. 1, що належить водночас до фракторів соціальності та фрормалізму.

Найменш важливими переважно вважають фрактори фрормалізму (кластери 1, 2, 4, 5, 7), соціальності $(4,6,7)$ та доступності $(3,5,6)$.

Аналіз демографрічних та соціальних характеристик продемонстрував, що вік, стать, готовність оплачувати навчання та середній бал чинників вибору форми БПР мають статистично вірогідну різницю. Це свідчить про адекватність запропонованої кластерної моделі. Водночас різниця між кластерами щодо типу населеного пункту та структури респондентів за рівнем лікарської кваліфрікації є статистично незначущою (табл. 2).

У середньому наймолодшими $є$ представники 4-го («невизначені») та 5-го («модерні ентузіасти»), а найстаршими - 3-го («агресивні негативісти») та 7-го («скептичні прагматики») кластерів. 3-й кластер також характеризується найбільшою часткою чоловіків (понад третина членів) і найнижчою середньою оцінкою чинників вибору фрорми БПР.

Найменше чоловіків (близько 115) у 6-му («консервативні ентузіасти»), 4-му («невизначені») та 2-му («модерні прагматики») кластерах, останні два також мають найвищий середній бал чинників вибору форми БПР.

Представники «ентузіастичних» 5-го та 6-го кластерів продемонстрували найвищу готовність оплачувати навчання самостійно, а найстарших 3-го та 7-го - найнижчу.

Серед форм навчання провідні позиції займають комбінована, очна та дистанційна. Очна і дистанційна форми є до певної міри протиставленими в уподобаннях користувачів, а комбінована добре сприймається всіма групами і виконує роль проміжної ланки (за рівнем залученості до навчання у реальному часі) між ними. Більш доступними респонденти вважають навчальні фрорми 3 дистанційним компонентом, а більш ефрективними - 3 очним. Таким чином, у парі «доступність - ефрективність» дистанційна фрорма зазвичай переходить у комбіновану, а комбінована - в очну (табл. 3).

Єдиним кластером, що в оцінці ефективних навчальних фрорм надав першість комбінованій (а не очній) фрормі, став 2-й («модерні прагматики»). А представники 3-го кластера стали єдиними, 

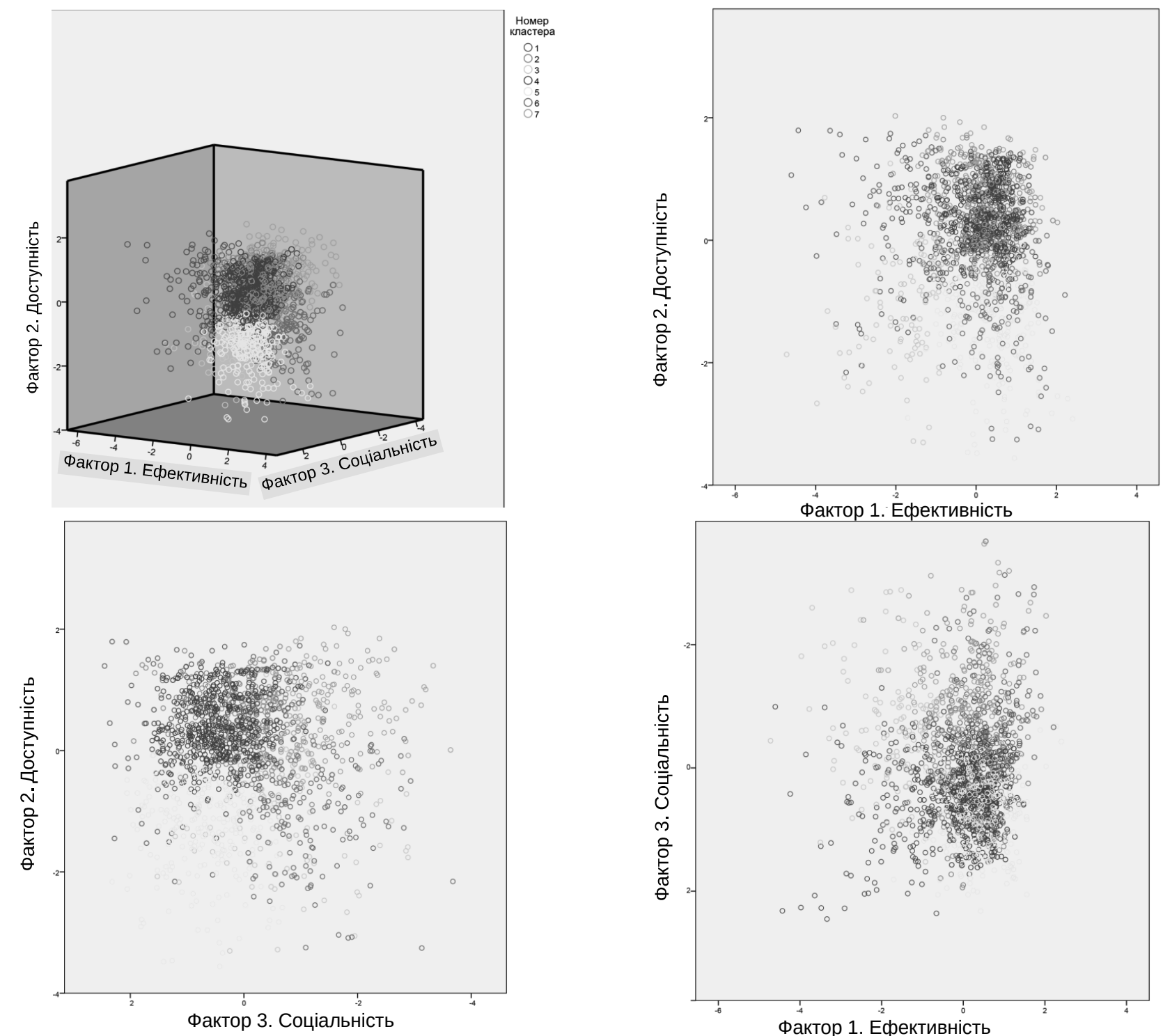

Puc. 1. Аксонометричне представлення отриманих кластерів у тривимірному просторі (ефективність доступність - соціальність) та їхніх двовимірних проекцій: прямої (верхня ліва), правої бічної (верхня права) та верхньої (знизу).

Таблиця 1. Медіанні значення факторів (за кластерами)

\begin{tabular}{|c|c|c|c|c|c|}
\hline Кластер & $\begin{array}{c}\text { Чисельність, } \\
\text { осіб }\end{array}$ & $\begin{array}{l}\text { Фактор } 1 \\
\text { (еоректив- } \\
\text { ність) } \\
\end{array}$ & $\begin{array}{c}\text { Фактор } 2 \\
\text { (доступність) }\end{array}$ & $\begin{array}{c}\text { Фактор } 3 \\
\text { (соціальність) }\end{array}$ & $\begin{array}{c}\text { Фактор } 4 \\
\text { (форормалізм) }\end{array}$ \\
\hline $\begin{array}{l}1 \\
\text { Легковажні екстраверти }\end{array}$ & 154 & $-1,5$ & 0,4 & 0,6 & $-0,5$ \\
\hline $\begin{array}{l}2 \\
\text { Модерні прагматики }\end{array}$ & 344 & 0,4 & 0,5 & 0,2 & $-0,6$ \\
\hline $\begin{array}{l}3 \\
\text { Агресивні негативісти }\end{array}$ & 116 & $-1,6$ & $-0,9$ & $-0,6$ & 0,6 \\
\hline $\begin{array}{l}4 \\
\text { Невизначені }\end{array}$ & 600 & 0,3 & 0,3 & 0,3 & 0,6 \\
\hline $\begin{array}{l}5 \\
\text { Модерні ентузіасти }\end{array}$ & 230 & 0,5 & $-1,2$ & 0,7 & $-0,4$ \\
\hline $\begin{array}{l}6 \\
\text { Консервативні } \\
\text { ентузіасти }\end{array}$ & 148 & 0,5 & $-1,0$ & $-1,1$ & 0,5 \\
\hline $\begin{array}{l}7 \\
\text { Скептичні прагматики }\end{array}$ & 176 & 0,0 & 0,7 & $-1,4$ & $-0,4$ \\
\hline
\end{tabular}


Таблиця 2. Демографічні та соціальні характеристики кластерів

\begin{tabular}{|c|c|c|c|c|c|c|}
\hline $\begin{array}{c}\text { Номер та розмір } \\
\text { кластера }\end{array}$ & $\begin{array}{c}\text { Тип населеного } \\
\text { пункту }\end{array}$ & $\begin{array}{l}\text { Вік, } \\
\text { роки }\end{array}$ & $\begin{array}{c}\text { Частка } \\
\text { чоловіків, } \\
\%\end{array}$ & $\begin{array}{l}\text { Лікарська } \\
\text { категорія }\end{array}$ & $\begin{array}{c}\text { Готовність } \\
\text { оплачувати } \\
\text { навчання, } \\
\%\end{array}$ & $\begin{array}{c}\text { Середній бал } \\
\text { оцінки чинників } \\
\text { вибору форори } \\
\text { БПР }\end{array}$ \\
\hline $\begin{array}{l}1 \\
\text { Легковажні } \\
\text { екстраверти } \\
\text { (154 особи) } \\
\end{array}$ & $\begin{array}{l}\text { Обласні центри, } \\
\text { м. Київ, } \\
\text { великі міста }\end{array}$ & $25-44$ & 29,4 & $\begin{array}{l}\text { Вища, } \\
\text { спеціаліст }\end{array}$ & 45,0 & 6,2 \\
\hline $\begin{array}{l}2 \\
\text { Модерні прагматики } \\
\text { (344 особи) }\end{array}$ & $\begin{array}{l}\text { м. Київ, обласні } \\
\text { центри, малі міста }\end{array}$ & $25-44$ & $21,2^{6}$ & $\begin{array}{l}\text { Вища, } \\
\text { спеціаліст }\end{array}$ & 52,8 & $7,7^{7}$ \\
\hline $\begin{array}{l} \\
\text { Агресивні негативісти } \\
\text { (116 осіб) }\end{array}$ & $\begin{array}{l}\text { м. Київ, обласні } \\
\text { центри, малі міста }\end{array}$ & $\begin{array}{c}\text { Понад } \\
45^{1}\end{array}$ & $37,2^{5}$ & $\begin{array}{l}\text { Вища, } \\
\text { спеціаліст }\end{array}$ & $35,3^{3}$ & $5,1^{7}$ \\
\hline $\begin{array}{l}4 \\
\text { Невизначені (600 осіб) }\end{array}$ & $\begin{array}{l}\text { м. Київ, обласні } \\
\text { центри, малі міста }\end{array}$ & $25-44^{2}$ & $22,1^{6}$ & $\begin{array}{l}\text { Вища, } \\
\text { спеціаліст }\end{array}$ & 42,6 & $8,9^{7}$ \\
\hline $\begin{array}{l}5 \\
\text { Модерні ентузіасти } \\
\text { (230 осіб) }\end{array}$ & $\begin{array}{l}\text { м. Київ, обласні } \\
\text { центри, малі міста }\end{array}$ & $25-44^{2}$ & 22,4 & $\begin{array}{l}\text { Вища, } \\
\text { спеціаліст }\end{array}$ & $65,8^{4}$ & 6,7 \\
\hline $\begin{array}{l}6 \\
\text { Консервативні } \\
\text { ентузіасти (148 осіб) }\end{array}$ & $\begin{array}{l}\text { м. Київ, обласні } \\
\text { центри, великі та } \\
\text { малі міста }\end{array}$ & $25-54$ & $19,9^{6}$ & $\begin{array}{l}\text { Вища, } \\
\text { спеціаліст }\end{array}$ & $54,1^{4}$ & 6,4 \\
\hline $\begin{array}{l}7 \\
\text { Скептичні прагматики } \\
\text { (176 осіб) }\end{array}$ & $\begin{array}{l}\text { Обласні центри, м. } \\
\text { Київ, малі міста }\end{array}$ & $25-54^{1}$ & 21,5 & $\begin{array}{l}\text { Вища, } \\
\text { спеціаліст }\end{array}$ & $36,2^{3}$ & 6,5 \\
\hline
\end{tabular}

Примітка. За даними дисперсійного аналізу виявлено такі статистично значущі відмінності $(p<0,05):{ }^{1}-$ найстарші кластери; ${ }^{2}$ - наймолодші кластери; ${ }^{3}$ - найнижча готовність оплачувати навчання; ${ }^{4}$ - найвища готовність оплачувати навчання; ${ }^{5}$ - найвища частка чоловіків; ${ }^{6}$ - найнижча частка чоловіків; ${ }^{7}-$ значущо відрізняються від усіх інших кластерів.

Таблиця 3. Ставлення кластерів до чинників доступності та ефективності навчання

\begin{tabular}{|c|c|c|c|c|}
\hline \multirow{3}{*}{ Номер та розмір кластера } & \multicolumn{4}{|c|}{ Чинники } \\
\hline & \multicolumn{2}{|c|}{ доступність } & \multicolumn{2}{|c|}{ ефрективність } \\
\hline & фрорма & тривалість, дні & орорма & тривалість, дні \\
\hline $\begin{array}{l}1 \\
\text { Легковажні екстраверти (154 особи) }\end{array}$ & $\begin{array}{l}\text { Дистанційна }{ }^{1}, \\
\text { комбінована }\end{array}$ & $5-6,2-3$ & $\begin{array}{l}\text { Очна², } \\
\text { комбінована }\end{array}$ & $5-6^{1}, 10-12$ \\
\hline $\begin{array}{l}2 \\
\text { Модерні прагматики (344 особи) }\end{array}$ & $\begin{array}{l}\text { Дистанційна } \\
\text { комбінована } \\
\text { ко }\end{array}$ & $5-6^{1}, 2-3^{a}$ & $\begin{array}{l}\text { Комбінована }{ }^{1}, \\
\text { очна }\end{array}$ & $5-6^{2}, 10-12^{a}$ \\
\hline $\begin{array}{l}3 \\
\text { Агресивні негативісти (116 осіб) }\end{array}$ & $\begin{array}{l}\text { Очна } \\
\text { комбінована } \\
\end{array}$ & $5-6^{1}, 2-3$ & $\begin{array}{l}\text { Очна }{ }^{2}, \\
\text { комбінована }\end{array}$ & $5-6^{1}, 10-12$ \\
\hline $\begin{array}{l}4 \\
\text { Невизначені (600 осіб) }\end{array}$ & $\begin{array}{l}\text { Дистанційна }{ }^{1}, \\
\text { комбінована }\end{array}$ & $5-6^{1}, 2-3^{b}$ & $\begin{array}{l}\text { Очна², } \\
\text { комбінована }\end{array}$ & $5-6^{1}, 10-12^{b}$ \\
\hline $\begin{array}{l}5 \\
\text { Модерні ентузіасти (230 осіб) }\end{array}$ & $\begin{array}{l}\text { Комбінована }{ }^{1}, \\
\text { дистанційна }^{1}\end{array}$ & $5-6^{1}, 2-3$ & $\begin{array}{l}\text { Очна } \\
\text { комбінована }\end{array}$ & $5-6^{1}, 10-12$ \\
\hline $\begin{array}{l}6 \\
\text { Консервативні ентузіасти (148 осіб) }\end{array}$ & $\begin{array}{l}\text { Комбінована², } \\
\text { дистанційна }\end{array}$ & $5-6^{1}, 2-3$ & $\begin{array}{l}\text { Очна², } \\
\text { комбінована }\end{array}$ & $5-6,10-12$ \\
\hline $\begin{array}{l}7 \\
\text { Скептичні прагматики (176 осіб) }\end{array}$ & $\begin{array}{l}\text { Дистанційна }{ }^{2}, \\
\text { комбінована }{ }^{1}\end{array}$ & $5-6^{1}, 2-3$ & $\begin{array}{l}\text { Очна }{ }^{1}, \\
\text { комбінована }^{1}\end{array}$ & $5-6^{1}, 10-12$ \\
\hline
\end{tabular}

Примітка. ${ }^{1}$ - рівень підтримки понад 30 \%; ${ }^{2}$ - рівень підтримки понад 40 \%. За даними дисперсійного аналізу:

a - прихильники коротших циклів; ${ }^{b}-$ прихильники довших циклів.

хто обрав очну фрорму не лише за ефективністю, але й за доступністю.

В оцінці оптимальної тривалості навчальних циклів представники всіх кластерів віддають пе- ревагу тижневим циклам, вважаючи при цьому 2-6-денні цикли більш доступними, а 5-12-денні - ефективнішими. Водночас проведення дисперсійного аналізу виявило статистично значущу 
різницю у середньому показнику оптимальної тривалості циклу: «модерні прагматики» тяжіють до коротших, а представники 4-го кластера - до триваліших циклів.

Серед фрорм навчання респонденти 1-6-го кластерів віддають перевагу майстер-класам та циклам стажування, 7-го - майстер-класам та дистанційному навчанню.

У попередній статті [1] була висловлена гіпотеза, що різниця у мотиваційній сорері між готовими та неготовими самостійно оплачувати навчання респондентами полягає у двох механізмах: орієнтації на результат та швидкості ухвалення рішень.

Застосувавши цей підхід, бачимо, що 1-й, 3-й та 7-й кластери мають нульові або негативні показники за фрактором ефективності, вищі значення показників доступності, низьку готовність оплачувати навчання. Зважаючи на це, вважаємо доречним відкласти або взагалі відмовитися від просування навчальних циклів у згаданих групах респондентів. 4-й кластер найбільший і не демонструє особливостей, окрім істотно вищого середнього бала оцінки чинників вибору форми БПР. Імовірно, це є ознакою дефіциту мотивації чи досвіду вибору форми БПР і вказує на потребу подальших досліджень цієї групи осіб.

Таким чином, найбільш перспективними для просування освітніх послуг є кластери 5, 6 та 2, які характеризуються високими показниками за фрактором ефективності, значно меншими (кластери 5, 6) або порівнянними (кластер 2) значеннями фрактора доступності та високою готовністю самостійно оплачувати навчання.

3 метою фрормування індивідуального мотиваційного портрета кожного кластера була перевірена статистична вірогідність:

1) різниці у рівнях високої (оцінки від 8 до 10 балів) чи низької (оцінки від 1 до 3 балів) підтримки кожного фрактора представниками різних кластерів (методом попарного порівняння з використанням поправки Бонфероні);

2) різниці між середніми оцінками кожного чинника представниками різних кластерів (методом однофракторного дисперсійного аналізу).

Відповідно до встановлених статистично вірогідних різниць у показниках визначали ступінь підтримки представниками кластера того чи іншого показника: середній (якщо кластери групи перебувають 3 обох боків від середньої оцінки всіх респондентів), вище або нижче середнього, високий або низький, дуже високий або дуже низький.

На основі проведеного аналізу розроблено відповідні рекомендації для трьох обраних кластерів.

Кластер 5 «Модерні ентузіасти»

Особливості кластера порівняно з іншими:
• висока важливість рекомендацій друзів, попередніх відгуків про цикл;

- вища за середню оцінка важливості попереднього досвіду навчання на кафедрі, наявності відкритої інорормації про цикл, діалогу з кафедрою, наявності матеріалів для дистанційного навчання, роботи з пацієнтами;

- нижча за середню оцінка важливості територіальної зручності, вартості циклу;

• низька важливість необхідності поїздки в інше місто, умов проживання.

Респонденти вище середнього оцінюють ефективність конференцій, дистанційного навчання, решта форм - на середньому рівні.

Аналіз та рекомендації

Оскільки кластер $€$ найбільш соціалізованим (і вочевидь достатньо інфрорматизованим), а на 2-му місці за важливістю є чинник наявності відкритої інформації про навчальні курси, доречним буде налагодити системне інфрормування про них у інтернеті.

Розробка та актуалізація уніфікованих описів навчальних циклів (курикулумів, силабусів), підготовка новин про навчання 3 акцентом на інтереси слухачів, забезпечення текстової, фото- та відеоверсій матеріалів (наприклад відгуки письмові та у фрорматі відеороликів, фротозвіти тощо).

Висока довіра до відгуків попередників, рекомендацій друзів та досвіду попереднього навчання на кафедрі свідчить про необхідність створення асоційованих 3 кафедрою або закладом спільнот випускників, в яких відбуватиметься обмін інфрормацією за мінімальної участі персоналу закладу.

Доречним буде налагодження двостороннього зв'язку зі слухачами 3 метою врахування їхньої думки в процесі оптимізації проходження циклу. 3 цією метою можлива організація відкритих і закритих опитувань, залучення слухачів у ролі експертів тощо. Важливо інфрормувати спільноту про впровадження рішень, прийнятих на основі такого діалогу, тобто - демонструвати відкритість комунікації та серйозне ставлення до думки слухачів.

Нагальною потребою є скорочення очного компонента навчальних програм без втрати якості підготовки. Для цієї групи користувачів доречною видається розбудова нових режимів чи форм підготовки: сесійного навчання (очні заняття у вихідні поєднані з дистанційною підготовкою упродовж тижня), майстер-класів тощо.

Члени кластера нечутливі до таких чинників доступності, як вартість циклу, територіальна зручність тощо, тож використання їх у просуванні освітніх послуг ймовірно буде малоефективним.

Кластер 6 «Консервативні ентузіасти»

Особливості кластера порівняно з іншими: 
- висока оцінка важливості участі міжнародних лекторів, діалогу з кафредрою;

- вища за середню оцінка важливості наявності матеріалів для дистанційного навчання, роботи 3 пацієнтами, лекторів-професорів та публічних осіб;

- нижча за середню оцінка важливості наявності відкритої інорормації про цикл, територіальної зручності, відгуків про цикл, необхідності поїздки в інше місто, умов проживання, вартості циклу;

• низька оцінка важливості рекомендацій друзів.

Респонденти вище середнього оцінюють ефективність конференцій, майстер-класів, циклів ТУ та ПАЦ.

\section{Аналіз та рекомендації}

Члени 6-го кластера мають близьке до 5-го співвідношення значень фракторів ефективності та доступності, але високо оцінюють чинники формалізму (наявність лекторів-професорів та публічних осіб) і низько - чинники соціальності. Найважливішими для респондентів цього кластера $€$ участь міжнародних лекторів, підтримка діалогу 3 кафедрою, наявність матеріалів для дистанційного навчання та робота з пацієнтами.

За такої ситуації критичним стає особистий досвід слухача: простота й зручність оформлення на цикл, персональний склад викладачів (залучення міжнародних та визнаних вітчизняних експертів), можливість здобуття та удосконалення практичних прийомів, реалізація очікувань від циклу та отримання передбачуваної гарантованої якості підготовки.

Для просування навчальних циклів тут варто залучати поштові розсилки інорормації про структуру та наповнення циклів (нові або заплановані цикли у фрорматі курикулумів). Вкрай важливим $€$ проактивно підходити до ведення офріційного веб-сайту, забезпечуючи постійну присутність інформації про майбутні цикли, оскільки для представників цього кластера веб-сайт є тим методом отримання інфрормації, який дозволяє уникнути соціальної взаємодії.

Ще одним методом просування освітніх послуг у цьому кластері слухачів $€$ інорормування про спектр надаваних освітніх послуг під час проходження циклу, наприклад у форматі невеликої брошури з каталогом навчальних циклів, зазначенням ключових лекторів та практичної складової курсу. Корисним може бути надання короткого опису системи якості, що діє у навчальному закладі, ключових міжнародних та вітчизняних стандартів, згідно з якими здійснюють підготовку, партнерів закладу та кафедри тощо.

Аналогічно до 5-го кластера доречним $€$ залучення слухачів з цієї групи до удосконалення навчального процесу через двосторонній діалог.

Кластер 2 «Модерні прагматики»

Особливості кластера порівняно з іншими:
- висока важливість територіальної зручності, необхідності поїздки в інше місто, умов проживання, вартості циклу;

- вища за середню оцінка наявності відкритої інорормації про цикл, завантаженості, важливості рекомендацій друзів, попередніх відгуків про цикл, участі міжнародних лекторів, діалогу з кафедрою, наявності матеріалів для дистанційного навчання, роботи з пацієнтами;

- нижча за середню важливість попереднього досвіду навчання на кафедрі, наявності лекторівпрофресорів;

- низька важливість наявності серед лекторів публічних осіб.

Респонденти значущо меншими балами (нижче середнього) оцінюють ефективність конференцій, циклів ТУ, ПАЦ; вище середнього - майстеркласи.

\section{Аналіз та рекомендації}

Позитивне значення чинників соціальності у 2-му кластері дозволяє застосовувати для просування послуг у цій групі користувачів комплекс заходів, запропонованих для 5-го кластера.

Водночас представники кластера більше за інших висловили зацікавлення у коротших (від 1 до 6 днів) та дистанційних циклах. Це необхідно враховувати під час планування освітньої діяльності, напружений тижневий цикл тематичного удосконалення може бути модифікований в аналогічний цикл за сесійною формою, де 2 дні здійснюватиметься дистанційна підготовка, а 3 (п'ятниця, субота, неділя) - очна.

Важливою відмінністю від 5-го та 6-го кластерів $\epsilon$ важливість для представників кластера чинників доступності: вартості циклу, територіальної зручності, необхідності поїздки в інше місто, умов проживання. Для подолання цих перешкод важливо не лише їх мінімізувати через управлінські заходи (вже згадане впровадження дистанційних технологій, удосконалення умов проживання в гуртожитку, впровадження електронної реєстрації на навчання тощо), але й переконливо демонструвати переваги, що стосуються важливих для представників кластера наявності відкритої інформації про цикл, завантаженості, важливості рекомендацій друзів, попередніх відгуків про цикл, участі міжнародних лекторів, діалогу 3 кафедрою, наявності матеріалів для дистанційного навчання, роботи з пацієнтами. Методом оптимізації витрат для цієї групи респондентів $€$ також розвиток комплексних освітніх заходів, під час проведення яких здійснюється низка окремих майстер-класів, науково-практичних конференцій, циклів тематичного удосконалення тощо.

\section{Висновки}

У результаті сегментування, здійсненого на основі аналізу 1768 анкет лікарів - споживачів 
освітніх послуг, виділено сім сегментів (кластерів), що характеризуються статистично вірогідними відмінностями у соціодемографічному та поведінковому аспектах.

На основі визначення вподобань користувачів, що стосуються бажаної фрорми та тривалості заходів БПР, різниці в оцінці важливості груп чинників вибору форми БПР (ефективності та доступності циклів, соціалізованості та орієнтованості на прийняті соціальні норми споживачів) вибрано найперспективніші для просування освітніх послуг кластери та запропоновано заходи з просування, що враховують визначені особливості.
Критичними завданнями є оптимізація освітнього процесу, спрямована на мінімізацію документообігу та часу відриву від роботи фрахівців (впровадження дистанційної реєстрації та дистанційного навчання), налагодження роботи 3 онлайн-медіа, а також облік, аналіз та комунікація з наявними освітніми послугами.

Перспективи подальших досліджень пов'язані з більш глибоким вивченням чинників впливу на вибір форми БПР, деталізацією структури кластерів та спрямовані на фрормування комплексу детермінант, що з високою імовірністю здатні прогнозувати поведінку особи у сорері БПР.

\section{Список літератури}

1. Гульчій О. П. Методологічні аспекти розробки навчальних програм для післядипломної освіти в охороні здоров'я / О. П. Гульчій, Н. М. Захарова // Науковий вісник Національного медичного університету імені О. О. Богомольця. 2010. - № 1. - С. 197-201.

2. Доказово побудована комунікація: необхідна передумова управління безперервним професійним розвитком / Ю. В. Вороненко, О. П. Гульчій, Н. В. Харченко та ін. // Український медичний часопис. - 2020. - Т. 2, № 4 (138). C. 1-4.

3. Комунікаційна компетенція як складова комплексного навчання фрахівців громадського здоров'я / Ю. В. Вороненко, О. П. Гульчій, І. М. Хоменко та ін. // Україна. Здоров'я нації. - 2017. - № 3 (44). - С. 309-310.

4. Betsch C. Cultural diversity calls for culture-sensitive health communication / C. Betsch, R. Bohm // Medical Decision Making. - 2016. - P. 795-797.

5. Grier S. Social marketing in public health / S. Grier, C. Bryant // Annu. Rev. Public Health. - 2005. - Vol. 26. - P. 319-339. 6. Guojun Gan. Data clustering theory, algorithms, and applications / Guojun Gan, Chaoqun Ma, Jianhong Wu // Philadelphia, Pennsylvania, USA: Society for Industrial and Applied Mathematics. - 2007.

7. Methodology for identification of healthstyles for developing effective behavior change interventions / E. Balku, G. Tóth, E. Nárai [et al.] // Journal of Public Health. - 2017. - Vol. 25. - P. 387-400.

8. Methods for communication processes enhancement in the "Provider-Consumer (Learner)" system of educational services / Y. Voronenko, O. Hulchiy, I. Khomenko [et al.] // Wiadomości Lekarskie. - 2020.

9. Moore, M. Distance Education: a systems view of online learning (3 edition вид.) / M. Moore, G. Kearsley. - 2011.

10. Navarro F. Profiles of attitudes toward healthcare: psychographic segmentation / F. Navarro. - 1990.

\section{References}

1. Hulchiy, O.P., \& Zakharova, N.M. (2010). Metodolohichni aspekty rozrobky navchalnykh prohram dlia pisliadyplomnoi osvity $v$ okhoroni zdorovia [Methodological aspects of curriculum development for postgraduate education in health care]. Naukovyi visnyk Natsionalnoho medychnoho universytetu imeni O.O.Bohomoltsia - Scientific Herald of O. Bohomolets National Medical University, 197-201 [in Ukrainian].

2. Voronenko, Yu., Hulchiy, O., Kharchenko, N., Zakharova, N., \& Balashov, K. (2020). Dokazovo pobudovana komunikatsiia: neobkhidna peredumova upravlinnia bezperervnym profesiinym rozvytkom [Evidence-based communication: a necessary prerequisite for continuous professional development management]. Ukrainskyi medychnyi chasopys - Ukrainian Medical Journal, 4 (138), 1-4 [in Ukrainian].

3. Voronenko, Yu. V., Hulchiy, O. P., Khomenko, I., Balashov, K., Turianytsia, S., \& lork, E. (2017). Komunikatsiina kompetentsiia yak skladova kompleksnoho navchannia fakhivtsiv hromadskoho zdorovia [Communication competence as a component of complex training of public health specialists]. Ukraina. Zdorovia natsii - Ukraine. The Health of the Nation, 3, (44).

4. Betsch, C., \& Bohm, R. (2016). Cultural diversity calls for culture-sensitive health communication. Medical Decision Making, 795-797.

5. Grier, S., \& Bryant, C. (2005). Social marketing in public health. Annu. Rev. Public Health, (26), 319-339.

6. Guojun Gan, Chaoqun Ma, \& Jianhong Wu. (2007). Data Clustering Theory, Algorithms, and Applications. Philadelphia, Pennsylvania, USA: Society for Industrial and Applied Mathematics.

7. Balku, E., Tóth, G., Nárai, E., Zsiros, E., Varsányi, P., \& Vitrai, J. (2017). Methodology for identification of healthstyles for developing effective behavior change interventions. Journal of Public Health (25), 387-400.

8. Voronenko, Y., Hulchiy, O., Khomenko, I., Zakharova, N., \& Balashov, K. (2020). Methods for communication processes enhancement in the "Provider-Consumer (Learner)" system of educational services. Wiadomości Lekarskie.

9. Moore, M., \& Kearsley, G. (2011). Distance Education: a systems view of online learning.

10. Navarro, F. (1990). Profiles of attitudes toward healthcare: Psychographic Segmentation. 
APPLYING PSYCHOGRAPHIC SEGMENTATION TO ESTABLISH COMMUNICATION IN THE FIELD OF DOCTORS' TRAINING

Yu. V. Voronenko, O. P. Hulchiy, N. M. Zakharova, K. V. Balashov

P. Shupyk National Medical Academy of Postgraduate Education, Kyiv, Ukraine

Purpose: to provide recommendations for targeted communication with key groups of consumers of continuing professional development (CPD) services based on previous segmentation.

Materials and Methods. The answers of 1768 respondents representing all regions of Ukraine, about the importance of factors in choosing the form of CPD subjected to factor analysis, which resulted in four factors were used as variables for cluster analysis (k-means method). The results were evaluated on the basis of descriptive statistics, the statistical probability of the difference was determined by pairwise comparison, and by analysis of variance.

Results. As a result of segmentation, carried out on the basis of the analysis of questionnaires of doctors consumers of educational services, four key factors of a choice of the form of CPD are revealed: professionalism, accessibility, the level of social activity, formalism of the student - on the basis of which seven clusters of students were formed, differing in socio-demographic and psychographic characteristics.

Conclusions. Critical tasks are the optimization of the educational process, minimizing the flow of documents and time off from work, establishing work with online media, accounting, analysis, communication with existing consumers of educational services.

KEY WORDS: continuous professional development; human resources; social marketing; cluster analysis; psychographic segmentation.

Рукопис надійшов до редакції 07.09.2020 p.

\section{Відомості про авторів:}

Вороненко Юрій Васильович - академік НАМН України, доктор медичних наук, професор, ректор

Національної медичної академії післядипломної освіти імені П. Л. Шупика; тел.: +38(044) 205-48-10.

Гульчій Олеся Петрівна - доктор медичних наук, професор, проректор з міжнародних зв'язків та науковопедагогічної роботи з іноземними громадянами Національної медичної академії післядипломної освіти імені П. Л. Шупика; тел.: +38(044) 205-48-16.

Захарова Надія Миколаївна - кандидат медичних наук, доцент, начальник відділу магістратури Національної медичної академії післядипломної освіти імені П. Л. Шупика; тел.: +38(044) 206-73-22.

Балашов Костянтин В'ячеславович - завідувач відділу комунікацій Національної медичної академії післядипломної освіти імені П. Л. Шупика; тел.: +38(044) 205-48-34. 